\title{
SUSCEPTIBILITY OF MONOSPECIES AND DUAL-SPECIES BIOFILMS OF STAPHYLOCOCCUS AUREUS AND ESCHERICHIA COLI TO ESSENTIAL OILS
}

\author{
F.M. MILLEZI ${ }^{1,4,5}$, M.O. PEREIRA4 ${ }^{4}$, N.N. BATISTA2 ${ }^{2}$, N. CAMARGOS ${ }^{2}$, I. AUAD², M.D.G. CARDOSO ${ }^{3}$ and \\ R.H. PICCOLI ${ }^{2}$ \\ ${ }^{1}$ Departamentos de Ciências Biológicas - Setor de Microbiologia Agrícola, ${ }^{2}$ Ciência dos Alimentos and ${ }^{3}$ Química, Universidade Federal de Lavras, \\ Lavras, Brazil \\ ${ }^{4}$ Departamento de Engenharia Biológica, Universidade do Minho, Braga, Portugal
}

\begin{abstract}
${ }^{5}$ Corresponding author. F.M. Millezi, Avenue Silvio Minecucci, 1695/304, Lavras 37200-000, Minas Gerais, Brazil. TEL: 55-35-91027008; FAX: 55-35-38291401; EMAIL:

amillezi@yahoo.com.br
\end{abstract}

Received for Publication January 31, 2012

Accepted for Publication June 4, 2012

doi:10.1111/j.1745-4565.2012.00387.x

\begin{abstract}
The aim of this study was to investigate the susceptibility of Staphylococcus aureus and Escherichia coli biofilms formed on the polypropylene surface. The cultures were developed for $240 \mathrm{~h}$, planktonic growth was characterized by colony-forming unit $(\mathrm{cfu}) / \mathrm{mL}$ and biofilms was characterized by quantifying biomass and $\mathrm{cfu} / \mathrm{cm}^{2}$. Essential oils (EOs) of citronella and lemon were extracted by hydrodistillation and characterized by gas chromatography. Biofilm formation occured after $3 \mathrm{~h}$ of contact. In dual-species biofilms, there was competition; S. aureus was the number of viable cells damaged by $E$. coli $(P<0.05)$. The EOs disinfectant action was similar in biofilms monospecies, viable cells and biomass decreased significantly. Dualspecies biofilms were more resistant to EOs. The action EOs on biofilm suggest promising alternatives to sanitize industrial polypropylene surfaces.
\end{abstract}

\section{PRACTICAL APPLICATIONS}

Historically, the majority of new drugs has been generated from natural products (secondary metabolites) and from compounds derived from natural products. The extracts of higher plants have been and still are widely used to obtain substances with antimicrobial action. However, their low concentration in the extract often makes the purification processes or the synergistic action of the different compound unfeasible, causing major problems for industries. Seeking to reduce the parameters involved in the isolation and purification of compounds, these essential oils (EOs) have been studied. They present high antimicrobial efficiency, and in appropriate concentrations they are considered safe. The antimicrobial activity of EOs was showed that such substances can be used with sanitizing agents in industrial surfaces against bacterial biofilms. However, this line of research is still very new, so it is important to continue research for the development of industrial sanitizing with EOs.

\section{INTRODUCTION}

The term biofilm was created to describe the sessile form of microbial life characterized by adhesion of microorganisms to biotic or abiotic surfaces, with consequent production of extracellular polymeric substances (Nikolaev and Plakunov 2007). In just two decades, we have learned that biofilms comprise highly structured matrix-enclosed communities (Costerton and Stewart 2001) whose cells express genes in a pattern that differs profoundly from that of their planktonic counterparts. Because direct observations show that biofilms constitute the majority of bacteria in most natural (Costerton et al. 1978) and pathogenic ecosystems (Costerton et al. 1999), it seems unwise to continue to extrapolate from planktonic cultures in studies of these systems. 
In the food industry, biofilms cause serious engineering problems such as impeding the flow of heat across a surface, increases in fluid frictional resistance of surfaces, and increases in the corrosion rate of surfaces leading to energy and production losses (Verran and Jones 2000). Pathogenic microorganisms grown on food surfaces and in processing environments can cross-contaminate and cause postprocessing contamination (Ganesh and Anand 1998). Several microorganisms are capable of participating in the adhesion processes and biofilm formation. In the food industry, these microorganisms can be classified as spoilage and pathogenic. Among the pathogenic microorganisms, Staphylococcus aureus and Escherichia coli are able to form biofilms, which are complex structures consisting of surface-attached bacteria surrounded by a self-produced extracellular polymer matrix (Kania et al. 2008; Naves et al. 2008).

Natural drugs could represent an interesting approach to limit the emergence and the spread of these organisms, which currently are potential sources of contamination that can lead to food deterioration or transmission of foodborne diseases. Recently, there has been considerable interest in the study of plant materials as sources of new compounds for processing into sanitizer agents. One approach may be the use of essential oils (EOs) that have been shown to be potential antibacterial agent (Nostro et al. 2007; Oliveira et al. 2010b; Millezi et al. 2012a,b). The results obtained are promising yet divergent. According to Chorianopoulos et al. (2008), the information available on the use of EOs as disinfectants is still limited, pointing to the need of further studies.

This work aimed at testing the susceptibility of biofilms formed by monospecies and dual-species of S. aureus and E. coli to EOs of lemon and citronella.

\section{MATERIALS AND METHODS}

\section{Experiment Execution Sites}

The experiment was carried out at the Federal University of Lavras (Lavras - MG, Brazil), in the Food Microbiology, Chromatography and Organic Chemistry, and in the University of Minho (Braga, Portugal), in Applied Microbiology Laboratory.

\section{Extraction, Identification and Quantification of the Compounds of EOs}

Fresh leaves of citronella and fresh peels of lemon were collected from Medicinal Plant Nursery of the Federal University of Lavras in Minas Gerais, Brazil. The EOs were extracted by hydrodistillation using a modified Clevenger apparatus (Sovereing, São Paulo, Brazil). Plant materials were chopped and placed with water in a 4 -L volumetric flask. The flask was coupled to the modified Clevenger apparatus, and the extrac- tion was performed for $2.5 \mathrm{~h}$ with the temperature maintained at approximately 100C. The hydrolate obtained was centrifuged at $321.8 \times g$ for $5 \mathrm{~min}$, with the EO being removed with a Pasteur pipette (Labor Import, Osasco, Brazil) and stored at refrigeration temperature in glass flasks wrapped in aluminum foil (Guimarães et al. 2008). Qualitative evaluation of EO was performed to gas chromatography coupled with mass spectrometry (GCMS) using the Shimadzu model GCMS - QP2010 Plus apparatus (São Paulo, Brazil). The operational conditions were: fused silica capillary column $(30 \mathrm{~m} \times 0.25 \mathrm{~mm})$ with DB5 bonded phase, helium carrier gas, flow rate $1 \mathrm{~mL} / \mathrm{min}$, injector temperature 220C, detector temperature $240 \mathrm{C}$, and oven temperature program $40 \mathrm{C}$, increasing $3 \mathrm{C} / \mathrm{min}$. The compounds were identified by comparisons with spectra existing in the library Wiley 8 and Flavors and Fragrances of Natural and Synthetic Compounds 1.2 , and by the Kovat's index (Adams 2007).

\section{Microorganism Standardization}

The microorganism used were E. coli American Type Culture Collection (ATCC) 25922 and S. aureus ATCC 24922. The standardization of the number of cells was determined by growth curve. Throughout the experiment, the strain was stored under refrigeration in freezing culture medium $(15 \mathrm{~mL}$ glycerol, $0.5 \mathrm{~g}$ bacteriological peptone, 0.3 of yeast extract and $0.5 \mathrm{~g} \mathrm{NaCl}$, per $100 \mathrm{~mL}$ of distilled water, with the final $\mathrm{pH} 7.4$ ) and stored at $-80 \mathrm{C}$. For strain reactivation and use, an aliquot of the freezing culture medium was transferred to test tubes containing trypticase soy broth (TSB, Merck, Lisbon, Portugal), with two subcultures at $37 \mathrm{C}$ for $24 \mathrm{~h}$. The culture was striated in trypticase soy agar (TSA, Merck) added to Petri dishes and incubated at $37 \mathrm{C}$ for $24 \mathrm{~h}$. Of the colonies formed on the TSA surface, some were removed and transferred into an Erlenmeyer flask containing $150 \mathrm{~mL}$ of TSB, which was incubated at $37 \mathrm{C}$ until approximately $10^{5} \mathrm{UFC} / \mathrm{mL}$.

\section{Preparation of the Coupons}

In order to initiate the bacterial adhesion stage, the polypropylene coupons were previously hygienized and sterilized in autoclave. For cleaning, the coupons were immersed in $0.3 \%$ peracetic acid at $50 \mathrm{C}$ for $30 \mathrm{~min}$ under $50 \mathrm{rpm}$ agitation. After, they were immersed in sterile distilled water at $80 \mathrm{C}$ for $15 \mathrm{~min}$. The coupons were autoclaved at $120 \mathrm{C}$ for $20 \mathrm{~min}$.

\section{Biofilm Formation on Polypropylene}

For biofilm formation, a Petri dish $(140 \times 20 \mathrm{~mm})$ containing $80 \mathrm{~mL}$ of TSB and polypropylene coupons $(10 \times 20 \mathrm{~mm})$ was used. After the addition of bacterial cultures (concentration $10^{5}$ colony-forming unit $[\mathrm{cfu}] / \mathrm{mL}$ ), the system was incubated at $37 \mathrm{C}$ under orbital agitation ( $50 \mathrm{rpm})$. Every $48 \mathrm{~h}$, the TSB used as substrate was replaced in the same amount of sterile TSB. At each medium change, the coupons were immersed in 
sterile water; nonadherent cells were removed, and the Petri dishes were replaced by sterile dishes. This procedure was carried out to complete $240 \mathrm{~h}$ of cultivation. To differentiate the process of adhesion and biofilm, the value of $10^{5} \mathrm{cfu} / \mathrm{cm}^{2}$ as biofilm, which is intermediate to that proposed by Andrade and Macêdo (1998), who set the value of $10^{7} \mathrm{cfu} / \mathrm{cm}^{2}$, and presented by Wirtanen et al. (1996) and Ronner and Wong (1993), which they regard as a biofilm adherent cell number of $10^{3}$ and $10^{5} \mathrm{cfu} / \mathrm{cm}^{2}$, was considered.

In monospecies S. aureus ATCC 25923 and E. coli ATCC 25922 were cultured in the previous system, individually, in the approximate amount of $10^{5} \mathrm{cfu} / \mathrm{mL}$. In dual-species, S. aureus ATCC 25923 and E. coli ATCC 25922 were inoculated together in the approximate concentration of $10^{5} \mathrm{cfu} / \mathrm{mL}$ of each microorganism.

\section{Quantification of Cultivable Planktonic Cells}

The planktonic cells number was determined, and aliquots of $1 \mathrm{~mL}$ of TSB were removed from the dish after 3, 48, 96, 144, 192 and 240 h. Every 48 h, the plates were replaced by other sterile, and TSB used as the substrate was replaced in the same amount of sterile medium, following the same procedure until the 10th day incubation. Serial dilutions up to $10^{-10}$ were carried out in test tubes containing $900 \mu \mathrm{L}$ of peptone solution. Aliquots of $100 \mu \mathrm{L}$ of each dilution were inoculated in Petri dishes containing TSA using the spread plate technique. The Petri dishes were incubated at $37 \mathrm{C}$ for $24 \mathrm{~h}$. The ability to detach and contaminate the sterile substrate was named as biotransfer potential (Oliveira et al. 2010a). The values were expressed total number of $\mathrm{cfu} / \mathrm{mL}$.

\section{Quantification of Cultivable Cells in Biofilm}

Cells adhered on polypropylene coupons were removed using sterile swabs performing standardized smear (100 times) on the coupon on both sides after $240 \mathrm{~h}$ of cultivation. The swabs were transferred to tubes containing $0.1 \%$ peptone water $(\mathrm{v} / \mathrm{v})$ and agitated in a vortex for $2 \mathrm{~min}$. After this procedure was performed, a serial dilution and aliquots of $0.1 \mathrm{~mL}$ were removed. The number of viable cells was determined by eosin methylene blue agar to count E. coli and Baird Parker agar for $S$. aureus using the technique of surface scattering. The dishes were incubated at $37 \mathrm{C} / 24 \mathrm{~h}$. After, this period took place on plate count, and the values were expressed in total number of cfus per unit area $\left(\log \mathrm{cfu} / \mathrm{cm}^{2}\right)$ (Silva et al. 2010). All assays were performed in three separate occasions.

\section{Biomass Quantification by Crystal Violet Staining}

Biomass of single and cocultive biofilms were quantified by crystal violet $(\mathrm{CV})$ staining method adapted from Stepanović et al. (2000). For fixation of the adhered cells and biofilms, the coupons were added in 12-well microtiter plates (Orange Scientific, Braine-l'Alleud, Belgium), and $2 \mathrm{~mL}$ of $99 \%$ methanol (Vaz Pereira, Lisbon, Portugal) was added to each well; after $15 \mathrm{~min}$, the methanol was removed, and the coupons were allowed to dry about $25 \mathrm{C}$. Then, $2 \mathrm{~mL}$ of CV stain $(1 \%$ $\mathrm{v} / \mathrm{v}$ ) (Merck) were added to all wells. After $5 \mathrm{~min}$, the excess of CV was removed, and the coupons were gently washed in water. Finally, $1 \mathrm{~mL}$ of acetic acid $(33 \% \mathrm{v} / \mathrm{v})$ (Pronalab, Lisbon, Portugal) were added to all wells to dissolve the CV stain, and the absorbance was measured at $570 \mathrm{~nm}$. All assays were performed in triplicate and on three separate occasions.

\section{Polypropylene Coupon Treatment Using Disinfectant Solutions}

For the elaboration of the disinfectant solutions based on EOs and control solution (without the EOs), the following proportions and dilutions suggested by Oliveira et al. (2010b) were used; with modification, the ethanol was substituted by dimethylsulfoxide (DMSO) 2\%. The saline solution was used to provide osmotic concentration adequate to the bacterial cell so that the bactericide effect would be attributed only to the EOs (Oliveira et al. 2010b). Tween 80 was used, as well as DMSO, to dilute the EOs. The EOs were initially diluted with DMSO, followed by the addition of the saline solution with $0.5 \%(\mathrm{v} / \mathrm{v})$ of Tween 80 . The amount of EO used in each disinfectant solution was based on previous studies about the bacteriostatic effect (Millezi et al. 2012a) on planktonic cell (data not shown) in concentration of $1.0 \%$.

After $240 \mathrm{~h}$, the coupons with biofilms were removed from Petri dishes and immersed in $0.1 \%$ peptone water for two consecutive times for the removal of planktonic cells. After, the coupons were dipped in sanitizing solutions for $15 \mathrm{~min}$ at 25C. After the treatment, the coupons were removed from solutions and subjected to smear performed with sterile swabs. The adhered cells were quantified and expressed in $\mathrm{cfu} / \mathrm{cm}^{2}$.

\section{Statistical Analysis}

The data were analyzed using the Prism software package (GraphPad Software, San Diego, CA). T-test and one-way analysis of variance test were performed, and $P<0.05$ was considered significant.

\section{RESULTS}

\section{Characterization of EOs and Disinfectant Action on Biofilms Single and Cocultive}

The chemical analyses showed that the monoterpenes were major chemical constituents. For EO citronella, the major 
TABLE 1. CHEMICAL COMPOSITION OF THE CYMBOPOGON NARDUS ESSENTIAL OIL

\begin{tabular}{llr}
\hline Constituents & \multicolumn{1}{c}{$\operatorname{Tr}^{*}$} & $\% \dagger$ \\
\hline Mircene & 12.468 & 0.23 \\
Limonene & 13.856 & 4.19 \\
Eucaliptol & 13.962 & 0.17 \\
Linalool & 16.600 & 0.86 \\
Isopulegol & 18.307 & 2.72 \\
Citronellal & 18.671 & 30.48 \\
Citronellol & 21.354 & 14.32 \\
Neral & 21.772 & 0.67 \\
Geraniol & 22.306 & 17.12 \\
Geranial & 22.807 & 0.87 \\
Citronelil acetate & 25.580 & 2.55 \\
Eugenol & 25.756 & 1.28 \\
Acetato de geranil & 26.582 & 1.91 \\
Elemeno & 26.935 & 1.22 \\
germacrene & 29.798 & 2.08 \\
murolene & 30.366 & 0.46 \\
$\alpha-$ cardinene & 30798 & 0.65 \\
$\beta$ - cardinene & 31.066 & 2.10 \\
Elemol & 31,852 & 6.11 \\
Naftalemol & 32,657 & 1.64 \\
Others & & 8.37 \\
Total & - & 100.00 \\
\hline Retention tim & &
\end{tabular}

* Retention time.

+ Percentage of the relationship between area and peak.

constituents found were citronellal (30.48\%), geraniol (17.12\%), citronellol (14.32\%) and elemol (6.11\%) (Table 1). Limonene (33.67\%), $\rho$-cimene (14.16\%), carvone $(9.50 \%)$ and ciclohexanodiol $(7.67 \%)$ were the main components for lemon (Table 2).

TABLE 2. CHEMICAL COMPOSITION OF THE CITRUS LIMONIA OSBECK ESSENTIAL OIL

\begin{tabular}{llr}
\hline Constituints & \multicolumn{1}{c}{$\mathrm{Tr}^{\star}$} & $\% \dagger$ \\
\hline$\alpha$-pinene & 10.257 & 1.03 \\
$\beta$-pinene & 11.851 & 4.30 \\
$\rho$-cimene & 13.702 & 14.16 \\
limonene & 13.866 & 33.67 \\
menthol & 17.365 & 1.26 \\
pinocarveol & 18.035 & 4.45 \\
pinocarvone & 18.926 & 1.39 \\
mirtenol & 20.172 & 4.20 \\
$t$-carvoel & 20.986 & 5.65 \\
c-carveol & 21.405 & 2.21 \\
carvone & 21.868 & 9.50 \\
ciclohexanodiol & 25.155 & 7.67 \\
Others & & 10.51 \\
Total & - & 100.00 \\
\hline
\end{tabular}

\footnotetext{
* Retention time.

+ Percentage of the relationship between area and peak.
}

\section{Growth of Planktonic Cells Associated with the Capacity of Biofilm Formation}

The E. coli and S. aureus planktonic monospecies growth was similar, with no significant difference $(P>0.05)$ and observed similar growth of both bacteria both in co-culture than in monospecies (Fig. 1a). The growth of E. coli along the $240 \mathrm{~h}$ provided monospecies no significant differences $(P>0.05)$. S. aureus after $3 \mathrm{~h}$ differed from 48, 96, 144, 192 and $240 \mathrm{~h}(P<0.05)$. However, the results shown in Fig. $1 \mathrm{~b}$ suggest that there was a relationship of competition in which E. coli predominated significantly in all times over $S$. aureus $(P<0.05)$. In periods 3,48 and $96 \mathrm{~h}$, there was a slight increase in the number of planktonic bacteria of $E$. coli, and in 144 and $192 \mathrm{~h}$, there was a decrease in the number of viable cells of $S$. aureus probably prejudiced by E. coli (Fig. 1b).

After $48 \mathrm{~h}$ of culture was observed the ability of microorganisms adhered in the coupons detached and contaminates the sterile medium, thus leading to potential biotransfer.

The E. coli monospecies biofilm at 3 and $48 \mathrm{~h}$ was statistically different from 192 and $240 \mathrm{~h}(P<0.05)$, and 96, 144 and $192 \mathrm{~h}$ were different from $240 \mathrm{~h}(P<0.05)$. A monospecies biofilm $S$. aureus formation in $3 \mathrm{~h}$ was significantly different from all other periods. For the biomass-accumulated simple biofilm of both bacteria, $3 \mathrm{~h}$ was statistically different only at 192 and $240 \mathrm{~h}$, and the times 48, 96, 144 and $192 \mathrm{~h}$ were different from 240 h (Fig. 2).

After 3 h of cultivation, both E. coli and S. aureus biofilm formed on the surface of polypropylene, both in monospecies and in dual-species (Fig. 2). After $240 \mathrm{~h}$ of E. coli simple biofilm formation, we observed a significant increase only between 3 and 144 h, 3 and 192 h, and 3 and $240 \mathrm{~h}(P<0.05)$. In $S$. aureus, simple biofilm after $3 \mathrm{~h}$ differed, which was obtained after 48, 96, 144, 192 and $240 \mathrm{~h}(P<0.05)$. In the dual-species the $\mathrm{cfu} / \mathrm{cm}^{2}$ number obtained after was different from just 3 and $144 \mathrm{~h}(P<0.05)$. Unlike biofilms constituted by bacteria in dual-species biofilm, both $E$. coli and $S$. aureus showed no significant differences in growth along the $240 \mathrm{~h}$ $(P>0.05)$.

In monospecies biofilms, the number of $S$. aureus viable cells was higher than E. coli; however, the difference was significant only in time $48 \mathrm{~h}$, as well as dual-species culture was also higher than E. coli in $48 \mathrm{~h}(P<0.05)$ (Fig. 3a). Fig. 3b shows that $E$. coli had a greater number of viable cells, and this difference was significant at 48, 96, 144 and $192 \mathrm{~h}(P<0.05)$.

\section{Sanitizing Action of EOs on the Biofilm}

The EOs of citronella and lemon had similar disinfectant action on monospecies biofilm E. coli and S. aureus, and viable cells decreased significantly (Fig. 4a) after treatment. Lemon EO decreased, respectively, 2.99 and $2.49 \log$ cfu of E. coli and S. aureus, citronella 3.64 and $2.51 \log$ cfu (Fig. 4a). 

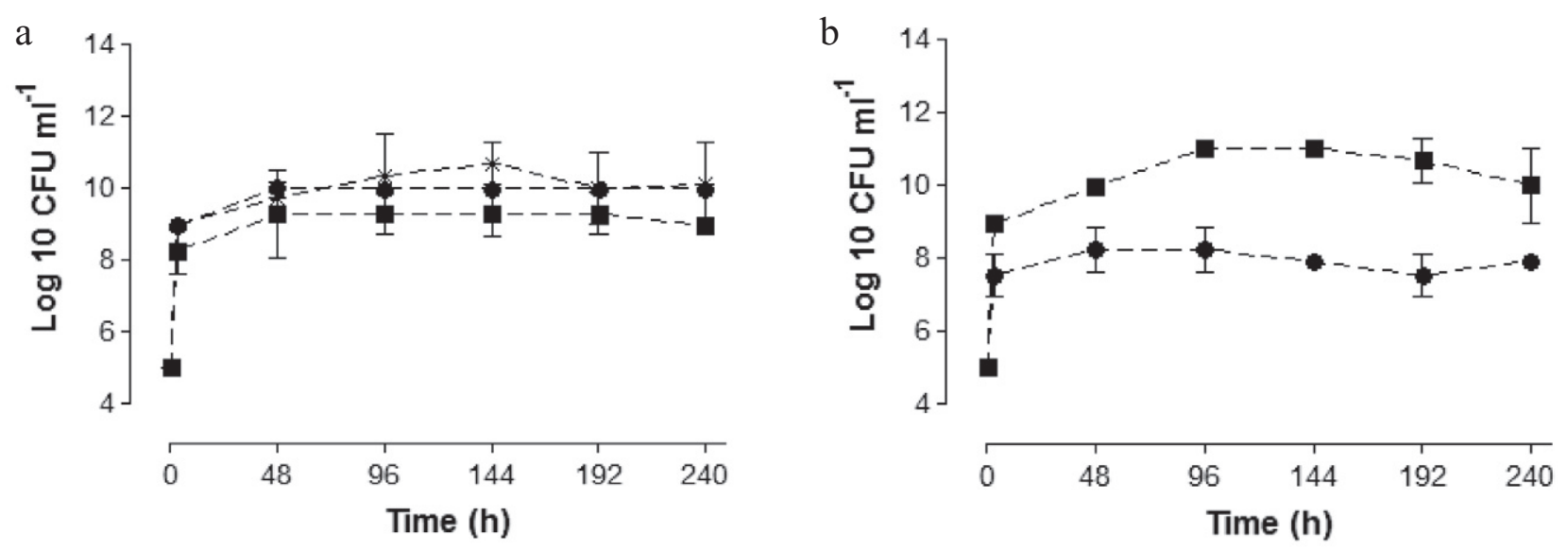

-Escherichia coli - - Staphylococcus aureus - *-Escherichia coli and Staphylococcus aureus

FIG. 1. CULTIVABLE PLANKTONIC CELLS OF STAPHYLOCOCCUS AUREUS AND ESCHERICHIA COLI IN TRYPTICASE SOY BROTH UNDER CULTIVATION SIMPLE AND MIXED (A) AND ONLY MIXED (B) AT 37C OVER $240 \mathrm{H}$

The accumulated biomass was also reduced significantly by comparing the results of the control (Fig. 4b).

Despite the interesting results, dual-species biofilm showed that there was greater resistance to EOs (Fig. 5). The lemon EO was more effective in reducing cultivable cells $(P<0.05)$ with a reduction of $4.63 \log \mathrm{cfu}$, and the treatment with citronella did not differ from control $(P>0.05)$, which reduced

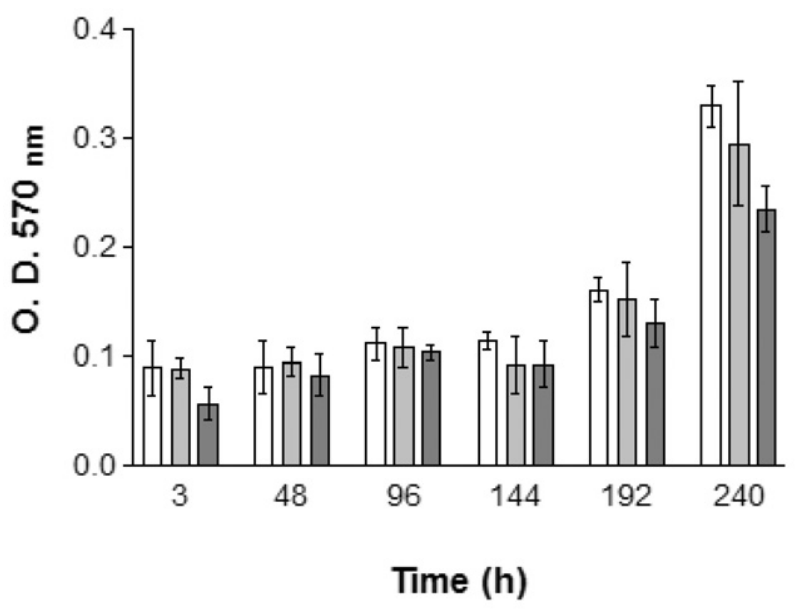

$\square$ E. coli $\square$ S. aureus $\square$ E. coli + S. aureus

FIG. 2. OD 570 VALUES AS A MEASURE OF SIMPLE AND DUALSPECIES BIOFILM MASS OF STAPHYLOCOCCUS AUREUS AND ESCHERICHIA COLI The means and standard deviations for at least three replicates are illustrated.
$2.72 \log$ cfu (Fig. 5a). Biomass again, lemon oil was more efficient; however, citronella biomass also decreased significantly $(P<0.05)$ (Fig. 5b).

In dual-species biofilm, E. coli and $S$. aureus were sensitive to EOs, but the action was better for E. coli, reduced lemon $4.65 \log \mathrm{cfu}$ and citronella $4.86 \log \mathrm{cfu} / \mathrm{cm}^{2}$. For S. aureus, there was reduction of only 1.52 and $1.75 \log \mathrm{cfu} / \mathrm{cm}^{2}$ through the action of EOs lemon and citronella, respectively (Fig. 6).

\section{DISCUSSION}

The biofilm formation is serious risk to the food industry because the removal of irreversibly adhered cells is difficult and requires the application of strong mechanical force or chemical interruption of the microbial adhesion using surfactants, sanitizers or heat. Thus, there is a high probability that the irreversibly adhered cells will remain even in the surfaces after sanitation. This is one of the main reasons for biofilm formation on surfaces in contact with food. This risk is aggravated by E. coli and S. aureus because this study observed that these bacteria have the capacity of rapidly adhering to polypropylene, being able to reach an irreversible stage in a few hours.

One of the great biofilm formation issues in the food industry or other areas is cell detachment, which makes it a constant source of microorganism contamination in food, water or new infection processes. Thus, the evaluation of the biotransfer potential of microorganisms is interesting. In present study, this can be observed from the values found after $48 \mathrm{~h}$ of biofilm formation. 


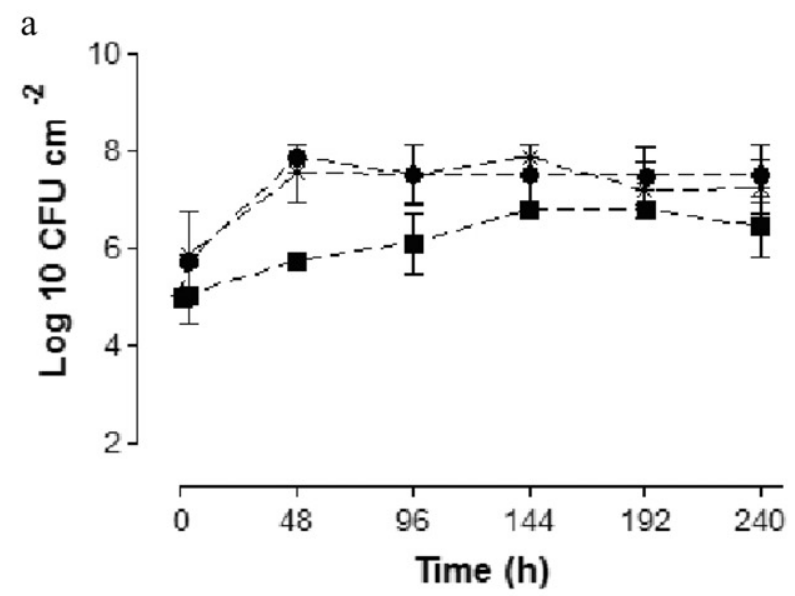

- Escherichia coli - $\bullet-$ Staphylococcus aureus b

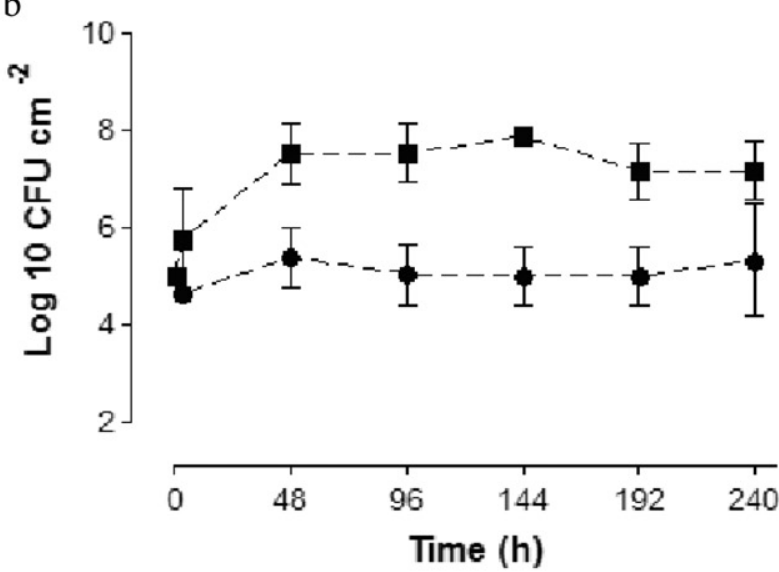

FIG. 3. BIOFILM CULTIVABLE CELLS OF STAPHYLOCOCCUS AUREUS AND ESCHERICHIA COLI IN TRYPTICASE SOY BROTH UNDER MONOSPECIES AND DUAL-SPECIES CULTIVATION (A) AND ONLY DUAL-SPECIES (B) AT 37C OVER $240 \mathrm{H}$

Significant differences are reported between different characteristics between planktonic bacteria and sessile. Ronner and Wong (1993) report up to $5 \log \mathrm{cfu} / \mathrm{cm}^{2}$ occurring genotypic and phenotypic processes that differentiate sessile from planktonic cells, indicating the formation of biofilms. According to Shank and Kolter (2009), many microorganisms can grow better in combination with other microorganisms. The present results show that the dualspecies association was a different situation compared with simple-species. In the present study, there was a competitive relationship in which S. aureus had the number of viable cells in biofilm hampered by the presence of E. coli $(P<0.05)$.

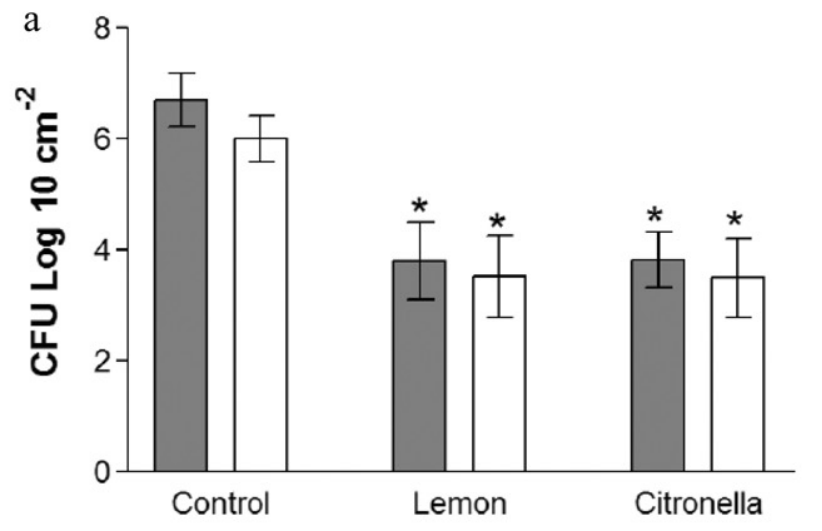

$\square$ Escherichia coli
Results similar to those found in this study were reported by Pompermayer and Gaylarde (2000) who investigated the adherence of S. aureus and E. coli, a condition that simplespecies and dual-species; they concluded that there is competition between bacteria, and the growth of $E$. coli is favored in dual species cultures.

Most research into interspecies interactions within biofilms have focused on the beneficial aspects of these relationships. However, not all interactions will be advantageous for the several interacting microorganisms. Antagonistic interactions may play an important role in the development and structure of microbial communities. Competition for substrates is considered to be one of the major evolutionary

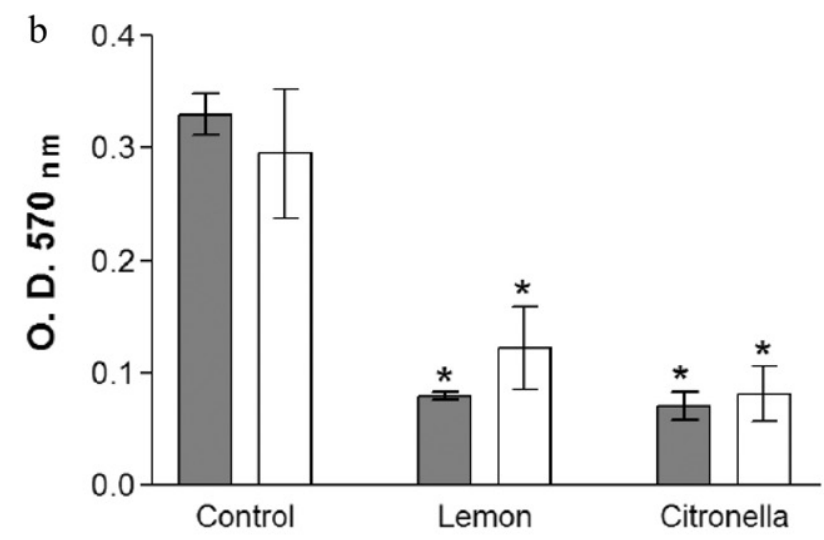

FIG. 4. EFFECT OF ESSENTIAL OILS ON CULTIVABLE CELLS (A) AND BIOMASS (B) OF SIMPLE-SPECIES BIOFILMS

The values are means of three separate assays, and the bars indicate standard deviation. ${ }^{*} P<0.05$ in one-way analysis of variance test. 

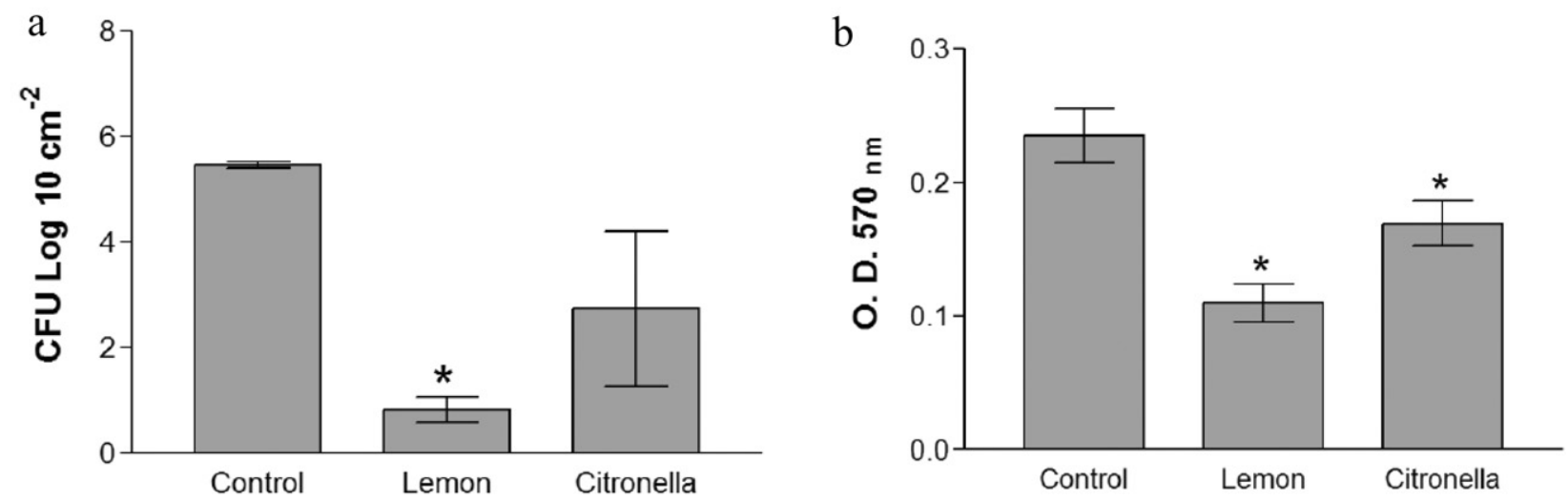

FIG. 5. EFFECT OF ESSENTIAL OILS ON CULTIVABLE CELLS (A) AND BIOMASS (B) OF DUAL-SPECIES BIOFILM

The values are means of three separate assays, and the bars indicate standard deviation. ${ }^{*} P<0.05$ in one-way analysis of variance test.

driving forces in the bacterial world, and numerous experimental data obtained in the laboratory under well-controlled conditions show how different microorganisms may effectively outcompete others as a result of a better utilization of a given energy source (Christensen et al. 2002; Komlos et al. 2005; Rao et al. 2005). The production of antagonistic compounds also seems to be a common phenomenon for some bacteria (Tait and Sutherland 2002; Rao et al. 2005; Bhattarai et al. 2006). Boari et al. (2009) investigated dual-species biofilms of S. aureus and Aeromonas hydrophila, and similar behavior occurred in the present research; S. aureus was approximately two log cycles lower than the simple biofilm.

In the food industry, a considerable number of surfaces such as stainless steel, glass, low density polyethylene, cast iron, rubber, polycarbonate and polypropylene are susceptible to microbial adhesion. However, the surface characteris-

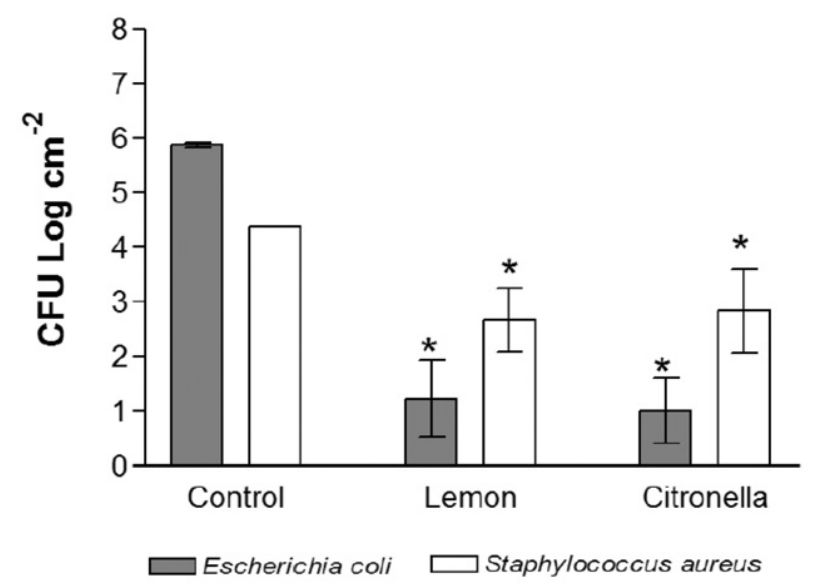

FIG. 6. EFFECT OF ESSENTIAL OILS ON CULTIVABLE CELLS OF ESCHERICHIA COLI AND STAPHYLOCOCCUS AUREUS IN DUAL-SPECIES BIOFILM

${ }^{*} P<0.05$ in one-way analysis of variance test $240 \mathrm{~h}$. tics such as electric charge, water retention capacity, free energy and topography have an important role in the accession process (Ploux et al. 2007). Shi and Zhu (2009) mention that the cells adhere better on hydrophilic surfaces (stainless steel, glass) than on hydrophobic surfaces (rubber and plastics). Currently, the use of polypropylene in the industry to build tanks, fittings, pipes and surfaces of food processing has grown rapidly (Lugão et al. 2007). According to Pompermayer and Gaylarde (2000), E. coli and S. aureus adhere to the polypropylene surface in $8 \mathrm{~h}$ at $12 \mathrm{C}$ and $30 \mathrm{C}$, but the adherence of $E$. coli was greater than $S$. aureus at both temperatures; in the present study, in $3 \mathrm{~h}$, there have been similar adherence in both microorganisms, demonstrating that adherence can be very fast on inadequately sanitized surfaces of polypropylene, with conditions favorable for the formation of biofilms.

Given the rapid acceptance and training biofilms E. coli and $S$. aureus are necessary new strategies in sanitizing surfaces used in the food industries; in this view are the natural antimicrobial agents derived from plant secondary metabolism: EOs.

The effectiveness of disinfectants is frequently determined by the number of surface-adhered cells they are capable to reduce, obtained by standard plate count. This work showed good results using the EOs of citronella leaves and lemon peels; we demonstrated that the EOs of lemon and citronella reduce E. coli $4 \log$ cfu and $S$. aureus $2.5 \log$ cfu. The effectiveness of EOs was similar to reduction in cfu of biofilms simplespecies, although dual-species biofilms were more resistant to citronella oil. In dual-species, E. coli was more sensitive to the action of the oils, and there was less cfu reduction of S. aureus, a little more than $1 \log$ cfu. Wide-spectrum antibacterial activities of EOs against gram-positive and gramnegative bacteria are well documented (Chorianopoulos et al. 2008; Sandasi et al. 2008; Oliveira et al. 2010b; Millezi et al. 2012a). 
Research on biofilm formed by other bacteria have also shown effective results; Oliveira et al. (2010b) achieved a reduction of $3.28 \mathrm{log}$ cfu of Listeria monocytogenes biofilm in the stainless steel surface disinfecting action of the EO of citronella.

The biologic activity of EOs on biofilms can be attributed to the compounds, majority of EOs. In this research, the chemical characterization of EOs is in accordance with the records of literature for the lemon oil; the compound majority limonene (Simões et al. 2004; Fisher and Phillips 2006) and citronella oil are the majority citronellal, citronellol and geraniol (Oliveira et al. 2010b), all belonging to the group of monoterpenes.

The mechanism of action of the monoterpenes (limonene, citronellal, citronellol, geraniol) involves mainly toxic effects on the structure and function of the cell membrane. As a result of their lipophilic character, the monoterpenes will preferably dislocate from the aqueous phase toward the membrane structures (Sikkema et al. 1995). Accumulation of the EO constituents in the lipid double layer of the cytoplasm membrane will confer a characteristic of permeability. In bacteria, cytoplasmic membrane permeabilization is associated to dissipation of the proton motive force regarding reduction of the adenosine triphosphate pool, internal $\mathrm{pH}$ and electric potential, and loss of ions such as potassium and phosphate ions (Bakkali et al. 2008).

Another fact observed in this study was the significant reduction of biomass accumulated, suggesting that the EOs interact with the matrix of exopolysaccharide (EPS) that is disrupted (Nostro et al. 2007).

Thus, it was concluded from the conditions studied that EOs lemon and citronella are new alternatives to sanitize industrial polypropylene surfaces contaminated by E. coli and $S$. aureus. We suggest further research on search strategies using natural antimicrobials against bacterial biofilms; there are few studies on this perspective.

\section{ACKNOWLEDGMENTS}

The authors thank the Coordenação de Aperfeiçoamento de Pessoal de Nível Superior (CAPES) for the first author's scholarship, the Fundação de Amparo à Pesquisa do estado de Minas Gerais (FAPEMIG) for the financial support, the Foundation for Science and Technology and European Community fund European Regional Development Fund (FEDER), in the ambit of the Project PTDC/SAUESA/ 6460912006/FCOMP-01-0124-FEDER-007480.

\section{REFERENCES}

ADAMS, R.P. (ed.) 2007. Identification of Essential Oils Components by Gas Chromatography/Mass Spectrometry, Allured Publishing Corporation, Carol Stream, IL.
ANDRADE, N.J. and MACÊDO, J.A.B. (eds.) 1998. Higienização na indústria de alimentos, Editora Varela, São Paulo, Brazil.

BAKKALI, F., AVERBECK, S., AVERBECK, D. and IDAOMAR, M. 2008. Biological effects essential oils: A review. Food Chem. Toxicol. 46, 446-475.

BHATTARAI, H.D., VISWANADH, G.S., PAUDEL, B., LEE, Y.K., LEE, H.K., HONGANG, Y.K. and SHIN, H.W. 2006. The study of antagonistic interactions among pelagic bacteria: A promising way ton environmentally friendly antifouling compounds. Hydrobiologia 568, 417-423.

BOARI, C.A., ALVES, M.P., REIS, V.M., SAVIAN, T.V. and PICCOLI, R.H. 2009. Formação de biofilme em aço inoxidável por Aeromonas hydrophila e Staphylococcus aureus usando leite e diferentes condições de cultivo. Ciênc. Tecnol. Ali. 29, 886-895.

CHORIANOPOULOS, N.G., GIAOURIS, E.D., SKANDAMIS, P.N., HAROUTOUNAIAN, S.A. and NYCHAS, G.J.E.. 2008. Disinfectant test against monoculture and mixed-culture biofilms composed of technological, spoilage and pathogenic bacteria: Bactericidal effect of essential oil and hydrosol of Satureja thymbra and comparison with standard acid - base sanitizers. J. Appl. Microbiol. 104, 1364-5072.

CHRISTENSEN, B.B., HAAGENSEN, J.A.S., HEYDON, A. and MOLIN, S. 2002. Metabolic commensalism and competition in a two-species microbial consortium. Appl. Environ. Microbiol. 68, 2495-2502.

COSTERTON, J.W. and STEWART, P.S. 2001. Battling biofilms. Sci. Am. 285, 75-81.

COSTERTON, J.W., GEESEY, G.G. and CHENG, K.J. 1978. How bacteria stick. Sci. Am. 238, 86-95.

COSTERTON, J.W., GEESEY, G.G. and CHENG, K.J. 1999. Bacterial biofilms: A common cause of persistent infections. Science. 284, 1318-1322.

FISHER, K. and PHILLIPS, C. 2006. The effect of lemon, orange and bergamot essential oils and their components on the survival of Campylobacter jejuni, Escherichia coli O157, Listeria monocytogenes, Bacillus cereus and Staphylococcus aureus in vitro and in food systems. J. Appl. Microbiol. 101, 1232-1240.

GANESH, C.K. and ANAND, S.K. 1998. Significance of microbial biofilms in food industry a review. Int. J. Food Microbiol. 42, 9-27.

GUIMARÃES, L.G. , CARDOSO, M., DAS, G., ZACARONI, L.M., DE LIMA, R.K., PIMENTEL, F.A. and DE MORAIS, A.R. 2008. Influence of light and temperature on the oxidation of the essential oil of lemon grass (Cymbopogon citratus [DC] Stapf). Quím. Nova 31, 1476-1480.

KANIA, R.E., GERDA, M.D., LAMER, E.L., VONK, M.J., DORPMANS, E., STRUIK, J., HUY BA, P.T., HIEMSTRA, P., BLOEMBERG, G.V. and GROTE, J. 2008. Characterization of mucosal biofilms on human adenoid tissues. Laryngoscope $118,128-134$.

KOMLOS, J., CUNNINGHAM, A., CAMPER, A. and SHARP, R. 2005. Interaction of Klebsiella oxytoca and Burkholderia cepacia 
in dual-species batch cultures and biofilms as a function of growth rate and substrate concentration. Microb. Ecol. 49, 114-125.

LUGÃO, A.B., OTAGURO, H., PARRA, D.F., YOSHIGA, A., LIMA, L.F.C.P., ARTEL, B.W.H. and LIBERMAN, S. 2007. Review on the production process and uses of controlled rhealogy polypropylene- gamma radiation versus electron beam processing. Radiat. Phys. Chem. 76, 1688-1690.

MILLEZI, A.F., CAIXETA, D.S., ROSSONI, D.F., CARDOSO, M.G. and PICCOLI, R.H. 2012a. In vitro antimicrobial properties of plant essential oils thymus vulgaris, cymbopogon citratus and laurus nobilis against five important foodborne pathogens. Ciênc. Tecnol.Ali. 32, 167-172.

MILLEZI, A.F., CARDOSO, M.G., ALVES, E. and PICCOLI, R.H. 2012b. Reduction of Aeromonas hidrophyla biofilm on stainless stell surface by essential oils. Braz. J. Microbiol. (in press).

NAVES, P., DEL PRADO, G., HUELVES, L., GRACIA, M., RUIZ, M., BLANCO, J., DAHBI, G., BLANCO, M., PONTE, C.M. and SORIANO, F. 2008. Correlation between virulence factors snd in vitro biofilm formation by Escherichia coli strains. Microb. Pathog. 45, 86-91.

NIKOLAEV, Y.A. and PLAKUNOV, V.K. 2007. Biofilm - "city of microbes" or an analogue of multicellular organisms? Microbiology 2, 125-138.

NOSTRO, A., ROCCARO, A.S., BISIGNANO, G., MARINO, A., CANNALETTI, M.A., PIZZIMENTI, F.C., CIONI, P.L., PROCOPIO, F. and BLANCO, A.R. 2007. Effects of oregano, carvacrol and thymol on Staphylococcus aureus and Staphylococcus epidermidis biofilms. J. Med. Microbiol. 56, 519-523.

OLIVEIRA, M.M.M., BRUGNERA, D.F., CARDOSO, M.G., ALVES, E. and PICCOLI, R.H. 2010a. Biofilm formation by Listeria monocytogenes on stainless steel surface and biotransfer potential. Braz. J. Microbiol. 41, 97-106.

OLIVEIRA, M.M.M., BRUGNERA, D.F., CARDOSO, M.G., ALVES, E. and PICCOLI, R.H. 2010b. Disinfectant action of Cymbopogon sp. essential oils in different phases of biofilm formation by Listeria monocytogenes on stainless steel surface. Food Control. 21, 549-553.

PLOUX, L. BECKENDORFF S., NARDIN M., and NEUNLIST S. 2007. Quantitative and morphological analysis of biofilm formation on self-assembled monolayers. Colloids Surf. B Biointerfaces 57, 174-181.

POMPERMAYER, D.M. and GAYLARDE, C.C. 2000. The influence of temperature on the adhesion of mixed cultures of
Sthapylococcus aureus and Escherichia coli to polypropylene. Food Microbiol. 17, 361-365.

RAO, D., WEBB, J.S. and KJELLEBERG, S. 2005. Competitive interactions in mixed-species biofilms containing the marine bacterium Pseudoalteromonas tunicata. Appl. Environ. Microbiol. 71, 1729-1736.

RONNER, A.B. and WONG, A.C.L. 1993. Biofilm development and sanitizer inactivation of Listeria monocytogenes and Salmonella Thyphimurium on stainless steel and buna-n rubber. J. Food Prot. 56, 750-758.

SANDASI, C.M., LEONARD, C.M. and VILJOE, A.M. 2008. The effect of five common essential oil components on Listeria monocytogenes biofilms. Food Control 19, 1070-1075.

SHANK, E.A. and KOLTER, R. 2009. New developments in microbial interspecies signaling. Curr. Opin. Microbiol. 12, 205-214.

SHI, X. and ZHU, X. 2009. Biofilm formation and food safety in food industries. Trends Food Sci. Technol. 20, 407-413.

SIKKEMA, J., DE BONT, J.A.M. and POOLMAN, B. 1995. Mechanisms of membrane toxicity of hydrocarbons. Microbiol. Rev. 59, 201-222.

SILVA, N., JUNQUEIRA, V.C.A., SILVEIRA, N.F.A., TANIWAKI, M.H., SANTOS, R.F.S. and GOMES, R.A.R. 2010. Manual de Métodos de Análise Microbiológica de Alimentos e Água, p. 624, 4th Ed., Varela, São Paulo, Brazil.

SIMÕES, C.M.O., SCHENKEL, E.P., GOSMANN, G., MELLO, J.C.P., MENTZ, L.A., PETROVICK, P.R. 2004. Farmacognosia: Da Planta ao Medicamento, p. 1102, 5th Ed., Universidade Federal do Rio Grande do Sul (UFRGS), Porto Alegre, Brazil.

STEPANOVIĆ, S., VUKOVIĆ, D., DAVIĆ, I., SAVIĆ, B. and ŜVABIĆ-VLAHOVIĆ, M. 2000. A modified microtiter-plate test for quantification of staphylococcal biofilm formation. J. Microb. Meth. 40, 175-179.

TAIT, K. and SUTHERLAND, I.W. 2002. Antagonistic interactions amongst bacteriocin-producing enteric bacteria in dual species biofilms. J. Appl. Microbiol. 93, 345-352.

VERRAN, J. and JONES, M. 2000. Industrial Biofouling, John Wiley and Sons Ltd., New York, NY.

WIRTANEN, G., HUSMARK, U. and MATTILA-SANDHOLM, T. 1996. Microbial evaluation of the biotransfer potencial from surfaces with Bacillus biofilms after rinsing and cleaning procedures in closed food-processing systems. J. Food Prot. 59, 727-733. 